\title{
COMPARATIVE STUDY OF SEVERAL MORPHOLOGICAL AND REPRODUCTIONAL ASPECTS FOR SOME SPECIES \\ OF THE BELLEVALIA LAPEYROUSE, 1808 AND ORNITHOGALUM LINNAEUS, 1753 (ASPARAGALES, ASPARAGACEAE) IN CENTRAL AND NORTH OF IRAQ
}

\author{
Najat Ameen Sa'eed* Naglaa Mustafa Al-Abide* \\ and \\ Aqeel Husein Ali Al- Asi** \\ *Department of Biology, College of Education for Pure Sciences, University \\ of Tikrit, Tikrit, Iraq \\ ** Department of Biology, College of Sciences, University of Tikrit. Tikrit, \\ Iraq \\ •Corresponding author: naglaa.mustafa@tu.edu.iq
}

Received Date: 11 August 2020, Accepted Date: 13 October 2020, Published Date: 21 December 2020

\section{ABSTRACT}

This study aims to study some morphological and reproductional characteristics in eleven species of two genera belonging to the family of Asparagaceae, which are Bellevalia Lapeyrouse, 1808 and Ornithogalum Linnaeus, 1753 and the species are: Bellevalia chrisii Yildirim and Sahin, 2014; Bellevalia flexuosa Boissier, 1854; Bellevalia kurdistanica Feinbrun, 1940; Bellevalia longipes Post, 1895; Bellevalia macrobotrys Boissier, 1853; Bellevalia paradoxa Boissier, 1882; Bellevalia parva Wendelbo, 1973; Bellevalia saviczii Woronow, 1927; Ornithogalum brachystachys C. Koch, 1849; Ornithogalum neurostegium Boissier, 1882 and Ornithogalum pyrenaicum Linnaeus, 1753. These species were identified and compared with each other; the results showed that there were differences between the two genera in studying the shape of bulbs, length of leaves and color of the flowers. Each of them showed an important taxonomic mark to be distinguished from the studied species. Morphological studies used with some characters of the reproductive, including the shape and color of the fruits, seeds and embryos were used to diagnoses the species. Also, the current investigation was found that the characteristics of the fruit and how it was connected to the pedicels was very important in the field of taxonomic and identification the species.

Two new record species were studied within the country, namely; Bellevalia chrisii and Bellevalia flexuosa; it should be noted here that the study of embryos is also one of the first studies conducted on these plants.

Keywords: Asparagaceae, Bellevalia, Morphological study, Ornithogalum, Seeds. 
Comparative study of several morphological and reproductional

\section{INTRODUCTION}

Plants of the Asparagaceae family are one of the wide spread plant families, they are distributed naturally in temperate, tropical-subtropical regions, mentioned by Antoine De Jussieu as the group of hexagonal plants with colored calyx (Jussieu, 1789). They include about 114 -143 genera and 3632 species (APGIII); for a long time they were a part from Liliaceae which has 220-250 genera and 3500 species, 21 genera are included in the Iraqi Botanical Encyclopedia (Townsend and Guest, 1985). Plants of this family are distinguished by being annual herbaceous shrubs that may be in the form of trees (Peruzzi, 2016). They are characterized by parallel striped green cauline leaves alternately arranged around the pedicel which is connected to an oval bulb; the importance of this family comes from the use of their plants for food such as onions and garlic, and the use of others for ornamental purposes, such as Asparagaceae, tulips, and other species, due to their beauty and bright colors ( $\mathrm{Li}, 2017)$.

The genus Bellevalia Lapeyrouse has an important variety within the family of Asparagaceae, which took a large part of the attention of researchers; the first to refer to it was the scientist Lapeyrouse (1808). It includes 50 species around the world, and 10 of them exist in Iraq according to (Hutchinson, 1959), and it is known as Al-'Ansalan or Al-Hawsalan with a bell-shaped violet flowers. As for the second genus that was studied, Ornithogalum Linnaeus, 1753 known as the star of Bethlehem (Purger et al., 2017), it has flowers that are white and rarely yellowish, it comprises about 150 species of which 8 are present in the Iraqi flora. This genus was referred to in the study of Oran and Odah (2015) on pollen grains of several species of the genus Ornithogalum within the Jordanian flora. According to recent literatures, these genera belong to Asparagaceae family (Chase et al., 2009). The studies done in Turkey by Firat et al. (2014), and Yildirim et al. (2014); in Iran by Jafari et al. (2016); and in Italy by Astuti et al. (2017), all classified the two genera within Asparagaceae family, while in Iraq there was only one study by Abdul-Raheem and Al-Bayaty (2018) that classified Bellevalia and Ornithogalum within Liliaceae.

The research examined the morphological aspects of the reproductive and vegetative parts of both genera, as this is one of the first bases relied upon in the field of plant taxonomy because of its simplicity, ease of diagnosis in the field, low cost and the possibility of conducting it by the naked eye; it is followed by most researchers in distinguishing between plant species and genera (Al-Abide, 2019; Yildirim and Sefali, 2020), as well as, the study focused on examination the shape of fruits and seeds and the study of embryos. This study is the first at the level of the country and the Arab world and there are a few studies that deal with different aspects such as that of Abdul-Raheem and Al-Bayaty (2018) which pointed out some morphological traits of both genera in Al-Uzaim region, the study of Çitak et al. (2015) which dealt with two species of the Ornithogalum within the Turkish flora, and the morphological and molecular study of the O. brevipedicellatum species by Aykurt et al. (2016). That of Pinar and Eroglu (2018) recorded the species of B. turcicas for the first time in Turkey, and the study of Baser et al. (2019) which focused on the shape of pollen grains for three species of the Bellevalia genus within the Turkish flora.

The aim of this study to study the morphological aspects: bulbs, leaves, scapouse, inflorescence, and reproductive characteristics such as fruits, seeds and embryos of eleven species belonging to the two genera of the Asparagaceae family. 


\section{Specimens' collection}

\section{MATERIALS AND METHODS}

Wild specimens of the plant species under study were collected from the central and northern regions of Iraq for each of the provinces of Salah-Al-Din: Al-Sharqat, Al-Hawija, Al-Alam, Al-Abbasi, Balad and Amerli districts; Nineveh Rabi'a, Zummar and Qayyara districts; Kirkuk: Kirkuk Center, Al-Hawija and Lower Zab districts; Erbil: Koysinjaq district only during 2019. Then, specimens were preserved by ethylene alcohol of $70 \%$ concentration, and stabilizing solution, F.A.A, until later used (Al-Abide, 2013 and 2016).

\section{Identification and morphological study}

The information about specimens was recorded; and they were identified by the second author based on (Hutchinson, 1959; Cullen, 1984; Townsen and Guest, 1985; Davis et al., 1988); also, the diagnosis was assured by comparing them with the specimens available at the National herbarium of Iraq. The morphological measurements of the plant species were carried out using a ruler, where the general length of plant, length of the root, length and width of the leaves and bulbs, the lengths of fruits and fruit pedicels were measured.

The fresh plant specimens were tested by a dissecting microscope with $2 \mathrm{X}$ and $4 \mathrm{X}$ powers, their dimensions were measured by the Ocular, and they were photographed by a digital camera.

\section{RESULTS AND DISCUSSION}

Through field study, it was found that all the species were perennial of herbaceous nature for Bellevalia species and all were annual for Ornithogalum species. They also spread in several areas, including Al- Sharqat, Al-Hawija, Rabi'a, the Hamrin Mountains, Erbil, Lower $\mathrm{Zab}$ and Amerli. Bulbs are found usually at a depth of $20-50 \mathrm{~cm}$ of soil; their blooming takes place for a period during spring in Iraq for 3-5 months.

\section{General appearance of the plants}

The results show that all species under study appeared with fibrous roots; $O$. pyrenaicum with longest root, it was $9.5 \mathrm{~cm}$; while it was shorter $(1 \mathrm{~cm})$ in $B$. parva, because the species of $O$. pyrenaicum was longer than B. parava. Through morphological examination, all of the species appeared with disc- shaped stem, and the stem width was greater in B. macrobotrys with $3.2 \mathrm{~cm}$, and $O$. neurostegium had the least width of $0.7 \mathrm{~cm}$.

Also we found the species had bulbs with different dimensions (Pl.1, 2; Tab.1), where the $B$. parva, O. brachystachys and $O$. neurostegium species were characterized by having elongated bulbs compared to others with oval bulbs; the B. kurdistanica species had the longest bulb with $6 \mathrm{~cm}$ length, whereas the shortest bulbs with $1.5 \mathrm{~cm}$ length were of $O$. neurostegium. The colors of these bulbs varied from pinkish white in $B$. parva and $B$. longipes, to brown in $B$. paradoxa, to yellowish white in the other species.

Except for B. chrisii and B. flexuosa which were collected from Erbil - Kasnazan mounts they were with acute apex, and $B$. parva with tubular leaves, as in Plate (3), the other species were similar with their striped blade. $O$. neurostegium species was distinguished by its distinctive leaves' shape, as it appeared with a curly blade, unlike the other two species, namely; $O$. brachystachys and $O$. pyrenaicum as they were distinguished by their stripped 
blades but with truncate or flat apex for $O$. pyrenaicum. The shape of the leaf's base varied between flat in the $B$. saviczii, B. macrobotrys, B. kurdistanica, B. chrisii, $O$. brachystachys, O. neurostegium, O. pyrenaicum species; tapered in B. flexuosa, $B$. longipes and B. paradoxa and obtuse in B. parva. Table (1) shows that B. kurdistanica had the longest leaves which reached $40 \mathrm{~cm}$, while $O$. neurostegium had the shortest with $15 \mathrm{~cm}$. B. flexuosa had the widest leaf with $4.5 \mathrm{~cm}$, and the least width was of O. pyrenaicum with $0.9 \mathrm{~cm}$. The three members of the Ornithogalum had smooth leaf bract which Bellevalia lacks, the longest was in the O. pyrenaicum, which was $3 \mathrm{~cm}$, and the species $O$. neurostegium had the shortest bracts with a length of $1.8 \mathrm{~cm}$. The widest leaf bracts were found in $O$. brachystachys with a width of $2.5 \mathrm{~cm}$, and the least width was found in the $O$. pyrenaicum, and was $2 \mathrm{~cm}$. Both the species; $O$. brachystachys and $O$. pyrenaicum, were distinguished by acute apex of the bract, while the bract of O. neurostegium was pointed. The three species were similar in having a smooth margin of the bract and a round base; the elongated shape of the leaf was important in the taxonomy of the species where $B$. saviczii was characterized by long curly leaves which helped to diagnose and differentiate it from the rest of the species, especially the B. kurdistanica and B. macrobotrys, as $B$. kurdistanica leaves were longer and wider than B. macrobotrys, and it was found that the width of the leaf also helped distinguish $B$. flexuosa from others because it had the widest leaf.

The results of the study are similar to that of Yildirim et al. (2014) who studied B. chrisii in terms of the elongated leaf shape, and it helped distinguish it from both B. rixii and B.crassa, and the study of Yetisen and Özdemir (2015) for O. alpigenum striped leaf shape was identical to that of the species of Ornithogalum, but differed from them by not mentioning the auricles that characterized the species of this genus.

The $B$. Chrisii was characterized by an oval scapouse whereas all the species were similar in having a circular scapouse. The longest scapouse was of the B. savcizii species, and its average was $45 \mathrm{~cm}$ whereas the shortest was $14.5 \mathrm{~cm}$ of the B. longipes. Style of attachment of the fruit pedicels with the flower ones was different; it was found that the fruit pedicels of the species $B$. chrisii and B. flexuosa were perpendicular to the flower-pedicels, and the B. parva were was having shorter fruit-pedicels $1.2 \mathrm{~cm}$ compared to the $B$. chrisii and $B$. flexuosa, $B$. kurdistanica and $B$. macrobotrys and $B$. saviczii, and the direction of the pedicels in $B$. parva was downward and not perpendicular to the flower pedicels as it was in the other types. The two species; $B$. macrobotrys and B. saviczii, were similar regarding the length of the fruit pedicels and by being perpendicular to the flower pedicels and at somewhat a straight angle.

With regard to the species of the Ornithogalum; it was found the fruit pedicels of the $O$. brachystachys facing upward and at an acute angle with the flower pedicels, while the $O$. neurostegium had a number of fruit less than the O. brachystachys and O. pyrenaicum, and the number of fruit was more in $O$. pyrenaicum compared to O. brachystachys and $O$. neurostegium, and the direction of fruit pedicels was at right to acute angles.

B. longipes and B. pycnanth were distinguished by the crowded inflorescences from the rest of the species that were distinguished by their spreading inflorescences as well as the violet colour of the flowers of the Bellevalia species, by which it was possible to distinguish them from the species of the Ornithogalum which had white colour flowers that matched the 


\section{Sa'eed et al.}

study of Aykurt et al. (2016), which indicated the white colour flowers with the central green midrib of the species of Ornithogalum, and the violate colour of the floral cover and the stamens of the Bellevalia species within the study of Jafari et al. (2016), which came in accordance with the results of the current study. The presence of bulbs and the difference in their shape between the oval and the elongated also helped to recognize them as taxonomic traits in the diagnosis of the studied species, which was similar to the study of Abdul-Raheem and Al-Bayaty (2018) that referred to these traits and for several wild species belonging to both genera.

All species were distinguished by having flowering raceme inflorescences consisting of perianth called tepals composed of 6 combined violet leaves in the species of the Bellevalia (Jafari et al., 2016), while the three species of the Ornithogalum had separated white six-leaf flowers with middle green midrib in the middle of perianth leaves which are combined with the sepal leaves (Pl. 1).
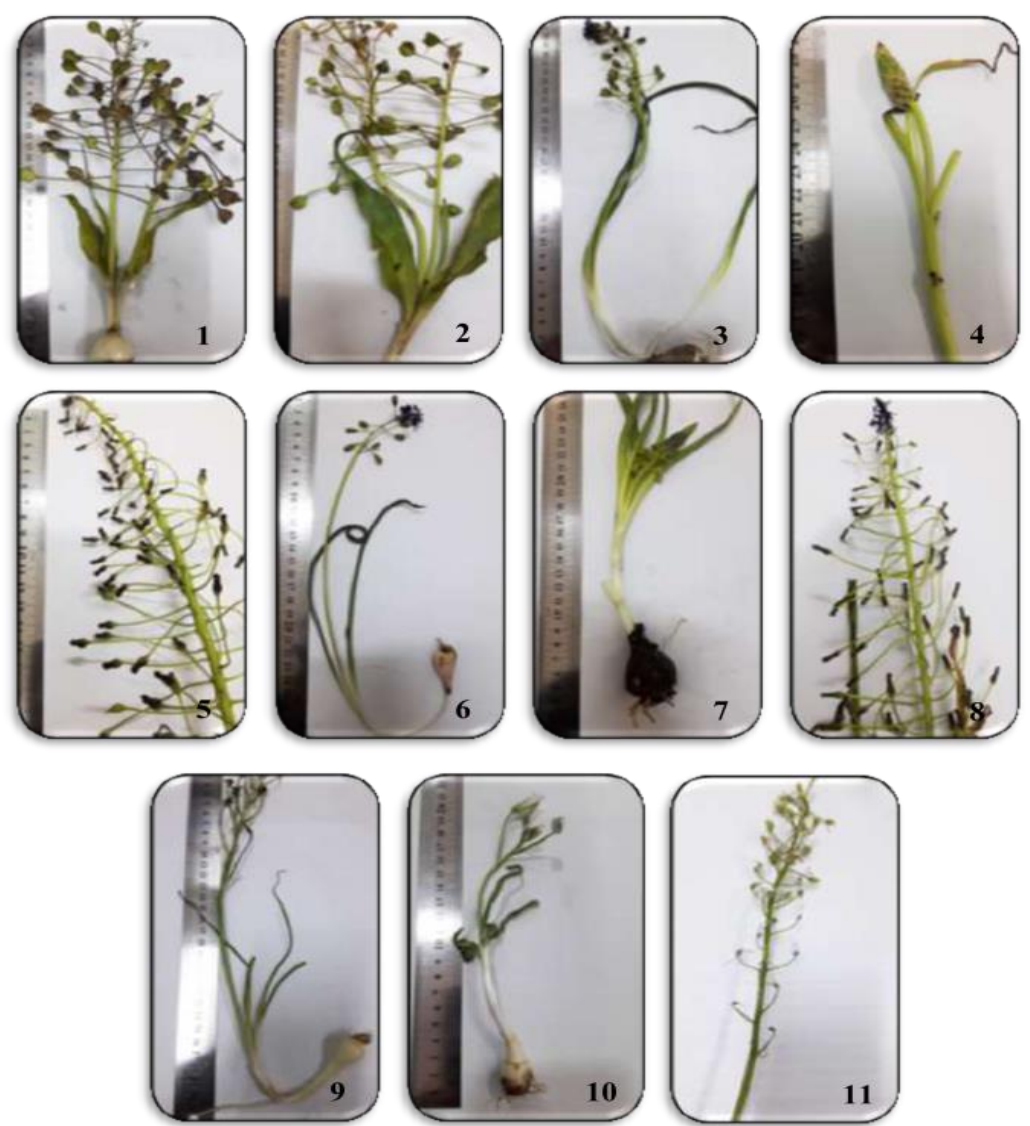

Plate (1): Morphological characteristics of the species; (1) Bellevalia chrisii, (2) B. flexuosa, (3) B. kurdistanica, (4) B. longipes, (5) B. macrobotrys, (6) B. parva, (7) B. paradoxa, (8) B. saviczii, (9) Ornithogalum brachystachys, (10) $O$. neurostegium, (11) O. pyrenaicum. 
Comparative study of several morphological and reproductional

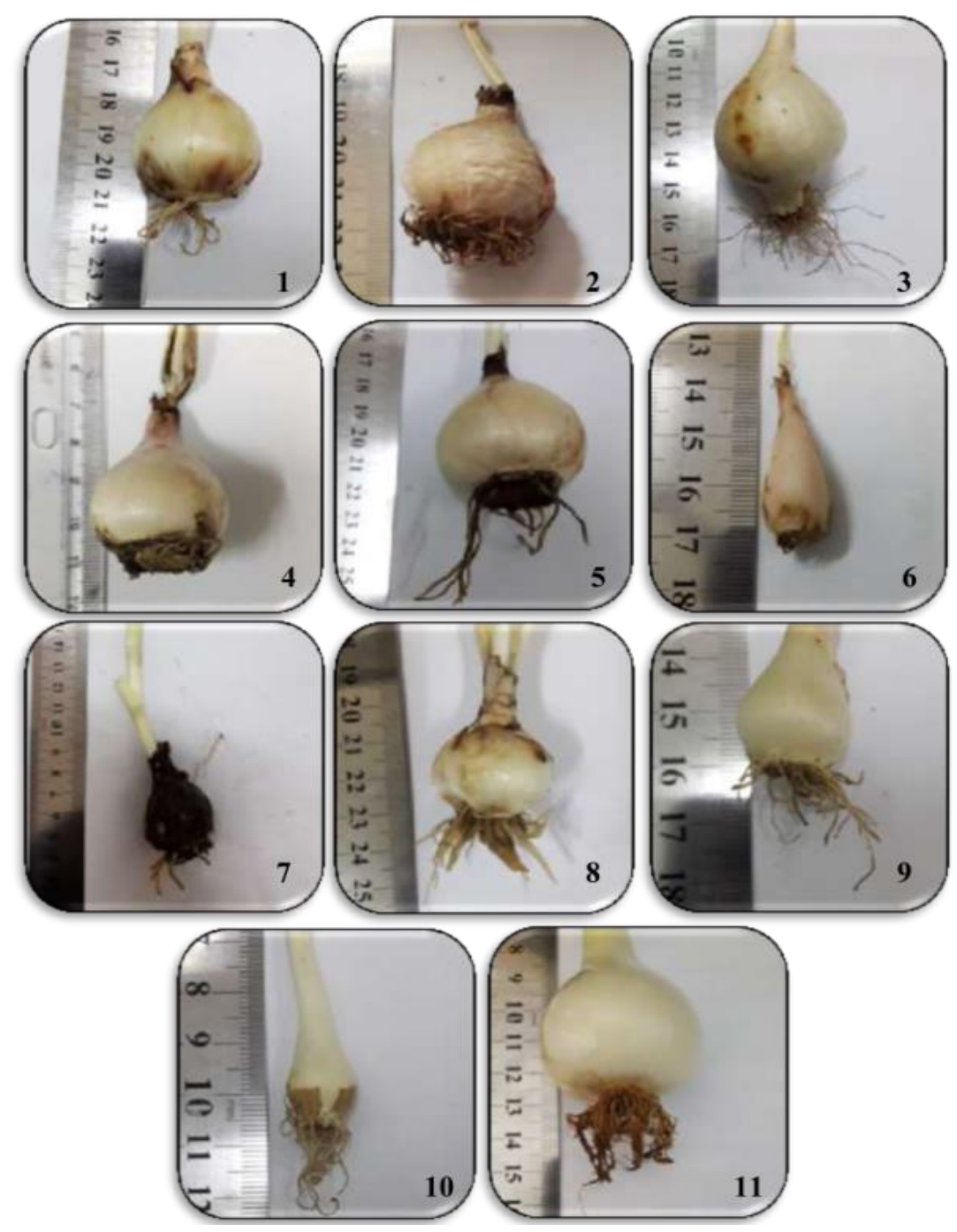

Plate (2): Quantitative and qualitative characteristics of bulbs the species studied; (1) Bellevalia chrisii, (2) B. flexuosa, (3) B. kurdistanica, (4) B. longipes, (5) B. macrobotrys, (6) B. parva, (7) B. paradoxa, (8) B. saviczii, (9) Ornithogalum brachystachys, (10) O. neurostegium, (11) O. pyrenaicum. 


\section{Sa'eed et al.}

Table (1): Quantitative and qualitative characteristicsof the roots, aerial stems, bulbs and leaves of plant species under current study.

\begin{tabular}{|c|c|c|c|c|c|c|c|}
\hline \multirow{3}{*}{ Species } & \multicolumn{7}{|c|}{ Characteristics } \\
\hline & \multirow{2}{*}{$\begin{array}{l}\text { Root } \\
\text { length } \\
(\mathrm{cm})\end{array}$} & \multirow{2}{*}{$\begin{array}{l}\text { Pedicel } \\
\text { length } \\
(\mathrm{cm})\end{array}$} & \multirow{2}{*}{$\begin{array}{c}\text { Bulb } \\
\text { length } \\
(\mathrm{cm})\end{array}$} & \multicolumn{2}{|c|}{ Leaf dimensions $(\mathrm{cm})$} & \multirow[b]{2}{*}{$\begin{array}{l}\text { Leaf } \\
\text { apex }\end{array}$} & \multirow[b]{2}{*}{$\begin{array}{l}\text { Leaf } \\
\text { base }\end{array}$} \\
\hline & & & & width & length & & \\
\hline B. chrisii & $\begin{array}{c}(2.5) \\
3.6-1.9\end{array}$ & $\begin{array}{c}(14.0) \\
19.5- \\
11.5\end{array}$ & $\begin{array}{c}(3.15) \\
4.5-2.5\end{array}$ & $\begin{array}{c}4.0-2.4 \\
(3.5)\end{array}$ & $\begin{array}{c}22.0-17.5 \\
(18.75)\end{array}$ & acute & truncate \\
\hline B. flexuosa & $\begin{array}{l}(1.85) \\
2.0-1.5\end{array}$ & $\begin{array}{c}(17.0) \\
18.5- \\
15.5\end{array}$ & $\begin{array}{c}(2.75) \\
4.0-2.5\end{array}$ & $\begin{array}{c}4.5-0.5 \\
(4.2)\end{array}$ & $\begin{array}{c}14.0-10.0 \\
(12.0)\end{array}$ & straight & obtuse \\
\hline B. kurdistanica & $\begin{array}{l}(2.75) \\
4.5-1.0\end{array}$ & $\begin{array}{c}(27.2) \\
35.0- \\
20.0\end{array}$ & $\begin{array}{c}(4.5) \\
6.0-3.0\end{array}$ & $\begin{array}{c}2.0-0.6 \\
(1.5)\end{array}$ & $\begin{array}{c}40.0-30.0 \\
(35.5)\end{array}$ & straight & truncate \\
\hline B. longipes & $\begin{array}{l}(1.06) \\
1.5-0.5\end{array}$ & $\begin{array}{c}(12.3) \\
14.5- \\
5.11\end{array}$ & $\begin{array}{c}(3.35) \\
4.3-2.5\end{array}$ & $\begin{array}{l}3.0-0.5 \\
(1.95)\end{array}$ & $\begin{array}{c}16.0-5.2 \\
(10.5)\end{array}$ & straight & obtuse \\
\hline B. macrobotrys & $\begin{array}{l}(3.37) \\
4.5-1.5\end{array}$ & $\begin{array}{c}(24.3) \\
37.0- \\
17.5\end{array}$ & $\begin{array}{c}(3.5) \\
5.0-2.0\end{array}$ & $\begin{array}{l}1.5-0.5 \\
(1.12)\end{array}$ & $\begin{array}{c}38.0-23.0 \\
(33.3)\end{array}$ & straight & truncate \\
\hline B. parva & $\begin{array}{l}(0.65) \\
1.0-0.5\end{array}$ & $\begin{array}{c}(15.3) \\
25.0-9.5\end{array}$ & \begin{tabular}{|c|}
$(1.75)$ \\
$3.0-0.9$ \\
\end{tabular} & $\begin{array}{l}1.2-0.5 \\
(0.78)\end{array}$ & $\begin{array}{c}22.5-16.0 \\
(18.3)\end{array}$ & acute & obtuse \\
\hline B. paradoxa & $\begin{array}{c}(2.55) \\
3.5-1.2\end{array}$ & $\begin{array}{c}(15.85) \\
18.5- \\
13.0 \\
\end{array}$ & $\begin{array}{c}(2.6) \\
3.5-1.7\end{array}$ & $\begin{array}{l}1.4-0.8 \\
(0.92)\end{array}$ & $\begin{array}{c}18.0-12.0 \\
(16.4)\end{array}$ & straight & obtuse \\
\hline B. saviczii & $\begin{array}{c}(1.75) \\
3.0-0.5\end{array}$ & $\begin{array}{c}(42.5) \\
45.0- \\
22.0\end{array}$ & $\begin{array}{c}(2.3) \\
3.2-1.5\end{array}$ & $\begin{array}{c}1.5-0.5 \\
(0.9)\end{array}$ & $\begin{array}{c}35.0-20.0 \\
(30.3)\end{array}$ & straight & truncate \\
\hline O. brachystachys & $\begin{array}{l}(2.35) \\
2.5-1.2 \\
\end{array}$ & $\begin{array}{c}(17.75) \\
20-14 \\
\end{array}$ & \begin{tabular}{|c|}
$(1.85)$ \\
$2.4-1.0$ \\
\end{tabular} & $\begin{array}{c}2.0-1.5 \\
(1.7) \\
\end{array}$ & $\begin{array}{c}18.0-7.0 \\
(12.6) \\
\end{array}$ & acute & truncate \\
\hline O. neurostegium & $\begin{array}{c}(0.9) \\
1.0-0.8\end{array}$ & $\begin{array}{c}(15.37) \\
18.0-9.5\end{array}$ & $\begin{array}{c}(1.25) \\
1.5-0.8\end{array}$ & $\begin{array}{c}5.0-2.5 \\
(2.8)\end{array}$ & $\begin{array}{c}15.0-5.0 \\
(8.6)\end{array}$ & acute & truncate \\
\hline O. pyrenaicum & $\begin{array}{c}(5.9) \\
9.5-1.5\end{array}$ & $\begin{array}{c}(26.5) \\
34.5- \\
21.0 \\
\end{array}$ & $\begin{array}{c}(3.75) \\
5.0-2.5\end{array}$ & $\begin{array}{c}0.9-0.2 \\
(0.6)\end{array}$ & $\begin{array}{c}26.0-15.0 \\
(16.5)\end{array}$ & straight & truncate \\
\hline
\end{tabular}

(Values between brackets represent the mean) 
Comparative study of several morphological and reproductional

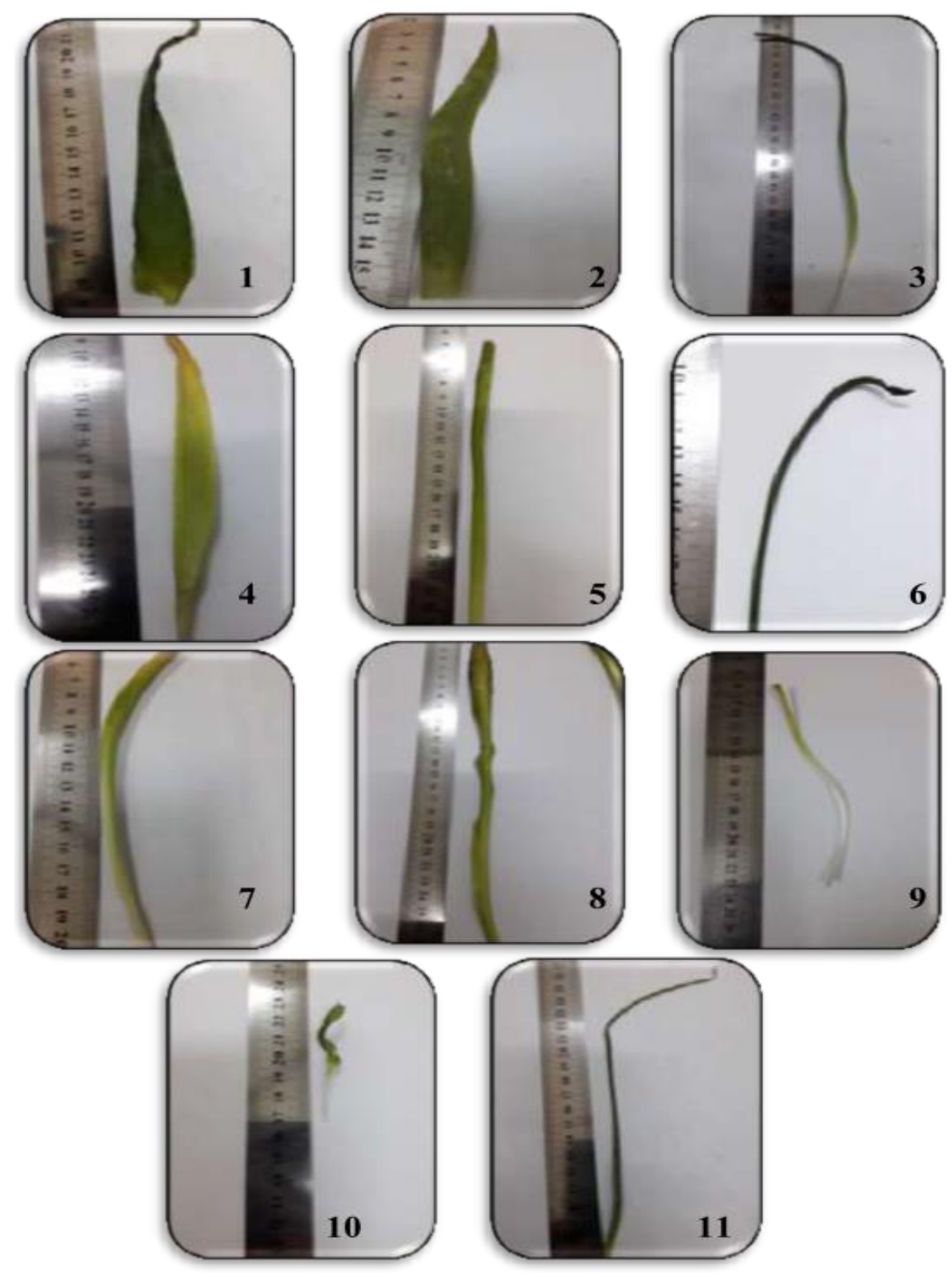

Plate (3): Quantitative and qualitative characteristics of leaves; (1) Bellevalia chrisii, (2) B. flexuosa, (3) B. kurdistanica, (4) B. longipes, (5) B. macrobotrys, (6) B. parva, (7) B. paradoxa, (8) B. saviczii, (9) Ornithogalum brachystachys, (10) $O$. neurostegium, (11) O. pyrenaicum. 


\section{Sa'eed et al.}

\section{Study of fruits and seeds}

Results of the study of the Bellevalia and Ornithogalum showed the similarity of the fruit type of their species, which was a trilobite capsule of green color for B. chrisii, B. flexuosa, $B$. kurdistanica, B. longipes, B. macrobotrys and B. parva, to light green for O. Brachystachys, $O$. neurostegium and $O$. Pyrenaicum as in Plate (4). The fruits appeared in a wide and large form in B. chrisii and oval in B. flexuosa, B. kurdistanica and B. macrobotrys.

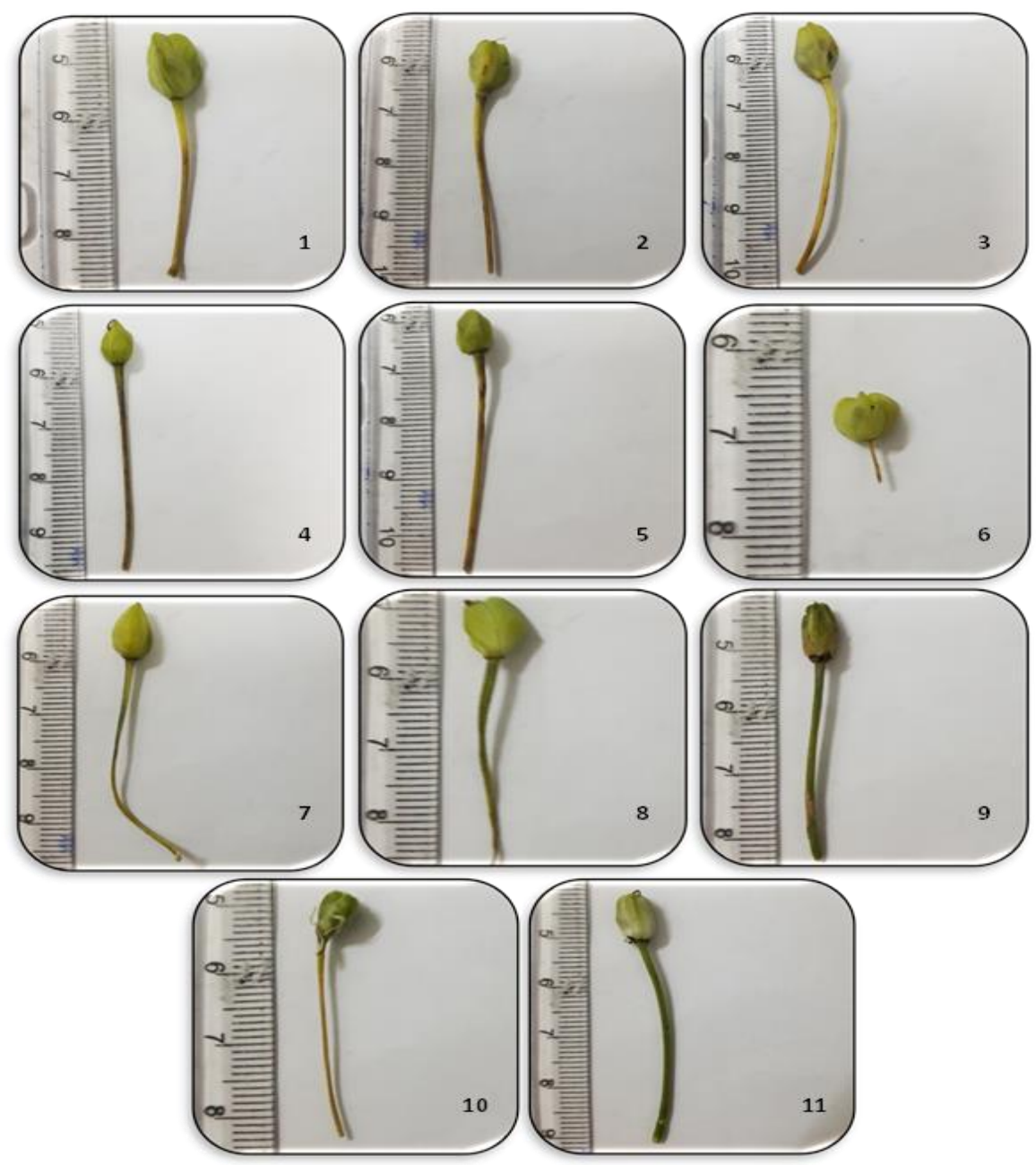

Plate (4): Fruit pedicels of the plant species under study; (1) B. chrisii, (2) B. flexuosa, (3) B. kurdistanica, (4) B. longipes, (5) B. macrobotrys, (6) B. parva, (7) B. paradoxa, (8) B. saviczii, (9) Ornithogalum brachystachys, (10) O. neurostegium, (11) O. pyrenaicum. 


\section{Comparative study of several morphological and reproductional}

The fruits of the species; $O$. brachystachys, O. neurostegium, and O. Pyrenaicum were characterized by an oval- shape striped with a white line and a green line, and the presence of bracts at the point of connection of the fruit with the fruit pedicels; the length of these pedicels varied between $6.5 \mathrm{~cm}$ in $B$. kurdistanica which was the longest, and $1.2 \mathrm{~cm}$ in B. parva which was the shortest. The number of these pedicels was about 65 in $B$. macrobotrys and $O$. pyrenaicum, and the fruits of $B$. chrisii and B. kurdistanica were large lobed in the form of an equilateral triangle, with a longitudinal slit at the apex of the separation of the fruit in the B. chrisii; and with elongated lobes in the form of an equilateral triangle in B. flexuosa. The $B$. longipes and $B$. paradoxa species had prominent lobed margins, with the connection mark of the style in triangular shape for B. longipes, and round for B. paradoxa. The fruit of $B$. macrobotrys was elongated of broad apex and the mark of the style's connection was bulgy while the fruit appeared in a near- asterisk form in $B$. parva with thin lobe margins. $B$. saviczii was distinguished by a two-lobed fruit, and the fruits of the three species of the Ornithogalum had no sharp corners and appeared in a spherical shape with lobes divided by linear lines. The fruits varied in the number of seeds between 8 seeds in the fruit of $O$. pyrenaicum, and 3 seeds in the fruit of B. flexuosa and B. longipes. As for B. chrisii, $B$. kurdistanica, B. macrobotrys, B. paradoxa and B. saviczii; their fruits contained 6 black colored seeds, their largest were in $B$. longipes with a length of $3.75 \mathrm{~mm}$ and the smallest in B. parva with a length of $1.3 \mathrm{~mm}$. The surface pattern of the seeds differed between reticular in B. chrisii, B. parva, B. saviczii, O. brachystachys, O. neurostegium, and O. pyrenaicum, and smooth surface in B. flexuosa, B. kurdistanica and B. longipes; and granular surface in $B$. macrobotrys and $B$. paradoxa (Pl. 5, Tab. 2), and these results are similar to the studies of Shuka (2014), Çitak et al. (2015) and Aykurt et al. (2016) regarding the capsule fruit shape and its importance in distinguishing between species; this matches what this study has concluded; $B$. macrobotrys was characterized by an elongated oval- shaped fruit with a prominent connection mark and this helped in distinguishing it from the rest of species, we also found that the difference in fruit pedicels' length was considered a taxonomic trait among species and this matches the study of Aykurt et al. (2016) which used the difference of fruit pedicels to distinguish between species of the Ornithogalum in a molecular and morphological study. 


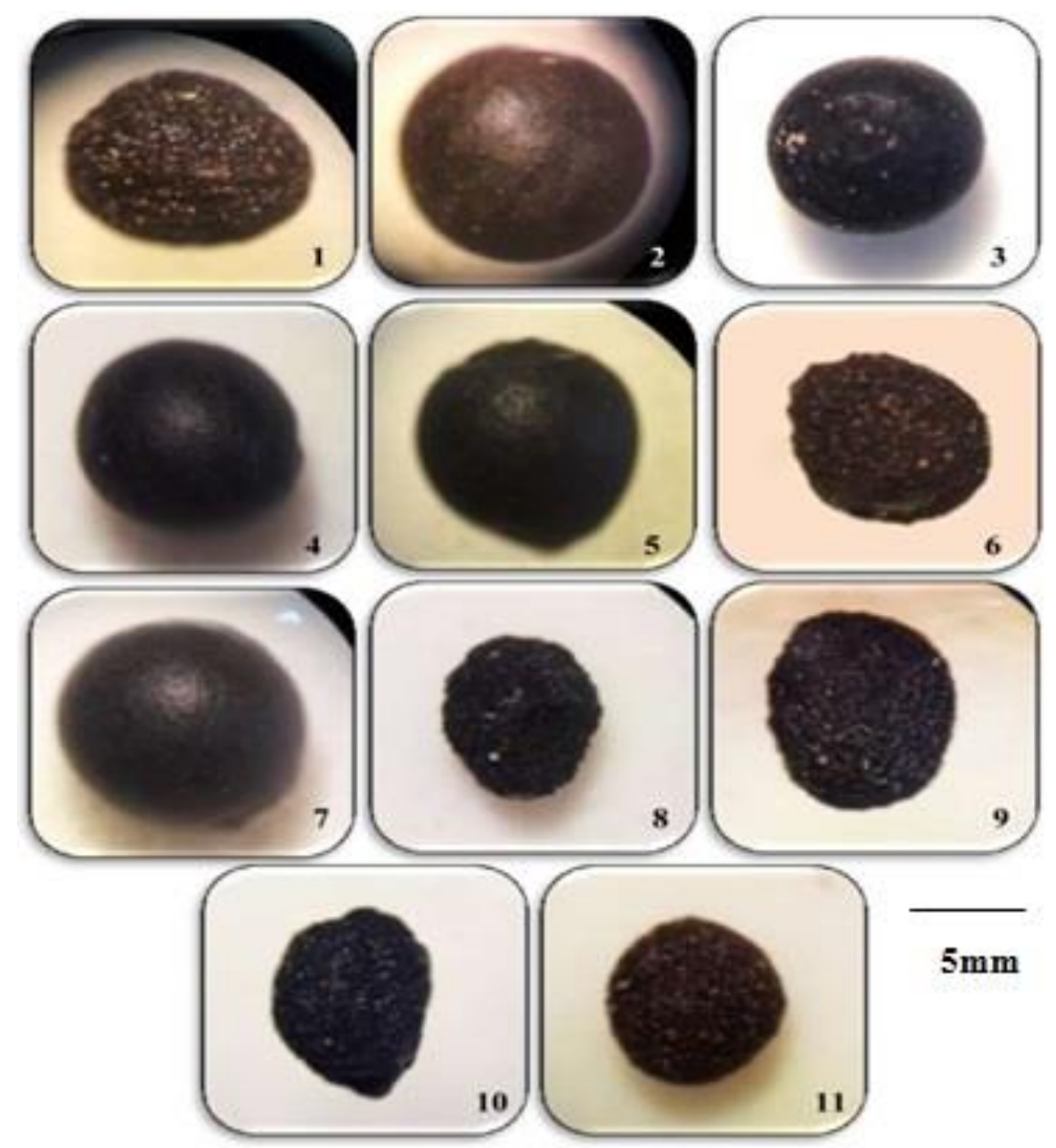

Plate (5): Morphological variations of seeds of plant species under study; (1) Bellevalia chrisii, (2) B. flexuosa, (3) B. kurdistanica, (4) B. longipes, (5) B. macrobotrys, (6) B. parva, (7) B. paradoxa, (8) B. saviczii, (9) Ornithogalum brachystachys, (10) O. neurostegium, (11) O. pyrenaicum.

The variation in seeds' shapes between spherical and oval had an additional taxonomic importance that contributed to the identification of the plant species under study, as the study of Mourad et al. (2010) was identical to the current study in terms of the spherical seed shape of species of the Bellevalia and contradicted with the study of Martinez-Azorin et al. (2010) which explained the seed shape of the $O$. brevipedicellatum was elliptical to spherical, also the results of this study are similar to that of Çitak et al. (2015); it confirms the oval shape, the black color and the reticular surface of the seeds of species of the Ornithogalum (Tab.3). 
Comparative study of several morphological and reproductional

Table (2): Quantitative characteristics of the fruit and fruit pedicels for the plant species under study.

\begin{tabular}{|l|c|c|c|c|c|}
\hline \multirow{2}{*}{ Species } & \multicolumn{5}{|c|}{ Characteristics } \\
\cline { 2 - 6 } & $\begin{array}{c}\text { Shape of } \\
\text { fruit }\end{array}$ & Length $(\mathrm{cm})$ & Width $(\mathrm{cm})$ & $\begin{array}{c}\text { Fruit pedicels } \\
\text { length }(\mathrm{cm})\end{array}$ & $\begin{array}{c}\text { Number of } \\
\text { seeds in } \\
\text { the fruit }\end{array}$ \\
\cline { 2 - 6 } B. chrisii & capsule & $1.7-0.8(1.2)$ & $1-0.5(0.76)$ & $5.5-2.5(4.37)$ & $6-2$ \\
\hline B. flexuosa & capsule & $1.0-0.6(0.72)$ & $0.8-0.5(0.7)$ & $5.0-3.5(4.5)$ & $3-1$ \\
\hline B. kurdistanica & capsule & $1.4-0.7(1.2)$ & $1.0-0.4(0.75)$ & $6.5-3.0(4.5)$ & $6-2$ \\
\hline B. longipes & capsule & $1.0-0.5(0.91)$ & $0.8-0.3(0.6)$ & $4.5-2.0(3.5)$ & $3-1$ \\
\hline B. macrobotrys & capsule & $1.2-0.5(1.11)$ & $1.2-0.5(0.95)$ & $6.0-3.0(4.5)$ & $6-2$ \\
\hline B. parva & capsule & $0.7-0.4(0.62)$ & $0.5-0.3(0.41)$ & $1.2-0.8(0.9)$ & $4-2$ \\
\hline B. paradoxa & capsule & $0.9-0.4(0.72)$ & $0.6-0.4(0.52)$ & $3.5-1.5(3.25)$ & $6-4$ \\
\hline B. saviczii & capsule & $1.5-1.0(1.16)$ & $1.0-0.7(0.90)$ & $6.0-4.0(3.25)$ & $6-2$ \\
\hline O. brachystachys & capsule & $1.0-0.7(0.85)$ & $0.6-0.3(0.55)$ & $4.2-1.0(2.5)$ & $5-3$ \\
\hline O. neurostegium & capsule & $1.4-0.5(0.78)$ & $0.8-0.4(0.6)$ & $3.5-1.2(2.08)$ & $4-1$ \\
\hline O. pyrenaicum & capsule & $0.9-0.5(0.81)$ & $0.5-0.2(0.45)$ & $6.0-3.0(4.2)$ & $8-4$ \\
\hline
\end{tabular}

(Values between brackets represent the mean)

Table (3): Quantitative characteristics of the seeds and embryos of plant species under study.

\begin{tabular}{|c|c|c|c|c|c|c|}
\hline \multirow[b]{3}{*}{ Species } & \multicolumn{6}{|c|}{ Characteristics } \\
\hline & \multicolumn{3}{|c|}{ Seeds (mm) } & \multicolumn{3}{|c|}{ Embryo $\mu$} \\
\hline & 营 & 吾 & 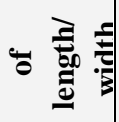 & 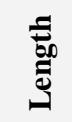 & $\stackrel{5}{5}$ & 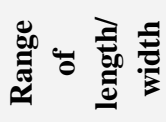 \\
\hline B. chrisii & (2.7) 3.0-2.5 & (1.6) 3.0-2.0 & 1.5 & 100 & 15 & 6.6 \\
\hline B. flexuosa & (2.5) 3.0-2.0 & (2.5) 3.0-2.0 & 1.0 & 80 & 12 & 6.6 \\
\hline B. kurdistanica & (2.5) 3.0-2.0 & (2.5) 3.0-2.5 & 1.0 & 120 & 25 & 4.8 \\
\hline B. longipes & (2.6) 3.5-2.5 & (2.6) 3.0-2.5 & 1.0 & 60 & 6 & 10.0 \\
\hline B. macrobotry & $\begin{array}{l}(1.14) \\
2.0-0.5\end{array}$ & (1.1) 2.0-1.0 & 1.1 & 118 & 40 & 2.9 \\
\hline B. parva & (1.6) 2.0-1.0 & (1.3) $1.5-0.5$ & 1.2 & 72 & 8 & 9.0 \\
\hline B. paradoxa & $\begin{array}{l}(3.25) \\
3.5-3.0\end{array}$ & (3.25) $3.5-3$ & 1.0 & 100 & 20 & 5.0 \\
\hline B. savcizii & $\begin{array}{l}(2.75) \\
3.0-2.0\end{array}$ & (1.75) 2.0-1.5 & 1.6 & 80 & 10 & 8.0 \\
\hline O. brachystachys & (2.7) 3.0-2.5 & (1.7) $2.0-1.5$ & 1.5 & 68 & 15 & 4.5 \\
\hline O. neurostegium & (2.4) 3.0-2.0 & (1.7) $2.5-1.5$ & 1.4 & 90 & 15 & 6.0 \\
\hline O. pyrenaicum & (1.7) $2.5-1.5$ & (0.9) $1.5-0.5$ & 1.8 & 105 & 20 & 5.25 \\
\hline
\end{tabular}

(Values between brackets represent the mean) 


\section{Study of Embryo}

Through microscopy, it was found that B. chrisii, B. kurdistanica, B. macrobotrys, B. parva, B. paradoxa, O. brachystachys, O. neurostegium, and $O$. pyrenaicum species had elongated embryos, whereas it was a curved- end embryo in B. flexuosa; B. longipes with a semi-curved embryo and a pointed end, and a curved embryo close to the crescent shape in the B. aviczii (Pl.6, Tab.3).

The results found that the embryos appeared in white colour in B. chrisii, B. kurdistanica, B. longipes, B. macrobotrys, B. parva, B. paradoxa, B. saviczii, O. brachystachys, O. neurostegium and $O$. pyrenaicum, and yellowish white in $B$. flexuosa and $B$. saviczii; we also noted that the B.kurdistanica, B. longipes, and B. saviczii species had a hat- shape structure, and the hat changed shape as it was wide and oval with a green colour in $B$. kurdistanica. In addition, $B$. longipes was distinguished by being yellow, pointed and similar to the arrowhead in B. saviczii. According to the Table (3), the results showed that the longest embryos were in $B$. kurdistanica reaching $120 \mu \mathrm{m}$ and the shortest were in $B$. longipes reaching $60 \mu \mathrm{m}$. B. macrobotrys had the widest with $40 \mu \mathrm{m}$ and the least width was of $B$. flexuosa and reached 12 $\mu \mathrm{m}$. The embryo and its study are of great importance in separating the species, as it was noticed that there were differences in their ends and colors, which motivated their adoption as prominent characteristics to distinguish the species $B$. kurdistanica, B. longipes and B. savcizii which were distinguished from the other species by their embryo as having a hat- like structure; the elongated shape of the embryos is due to the fact that these plants are monocots, which are distinguished by elongated embryos.

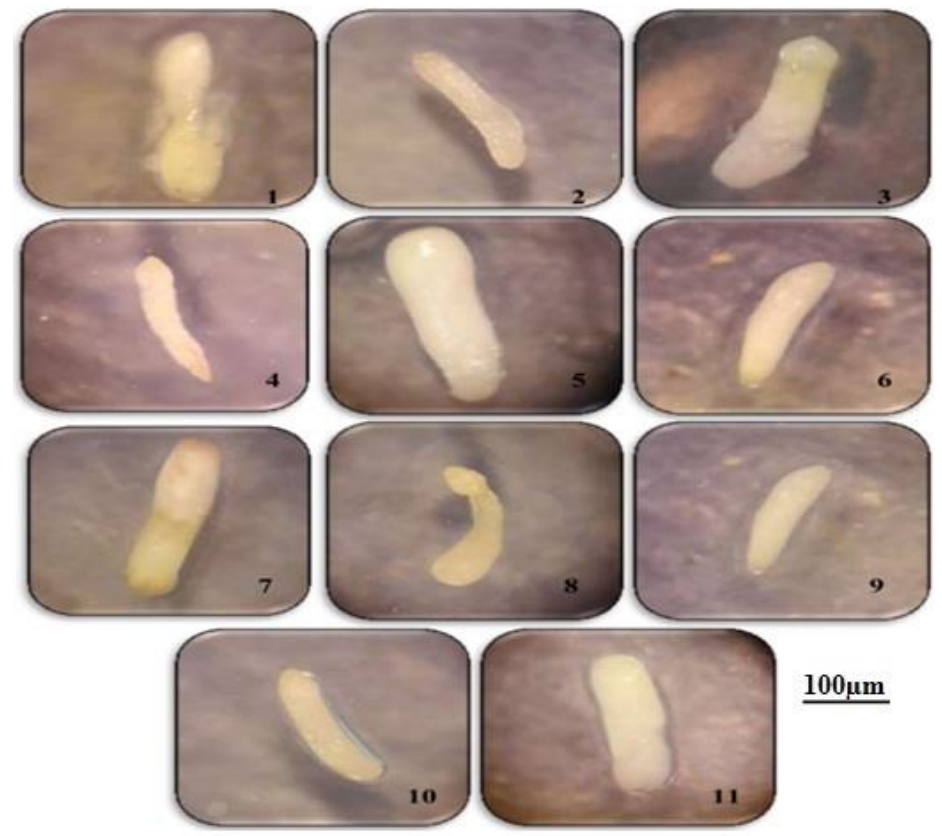

Plate (6): Qualitative characteristics of the embryos of plant species; (1) Bellevalia chrisii, (2) B. flexuosa, (3) B. kurdistanica, (4) B. longipes, (5) B. macrobotrys, (6) B. parva, (7) B. paradoxa, (8) B. saviczii, (9) Ornithogalum brachystachys, (10) $O$. neurostegium, (11) O. pyrenaicum. 
Comparative study of several morphological and reproductional

\section{Description of $B$. chrisii}

Bulb globose - ovoid, 2.5-4.5 cm in diameter, with a coriaceous outer tunic, brownish, and papery inner tunic, light brownish. Leaves $17.5-22 \mathrm{~cm}(18.75 \mathrm{~cm})$, lanculate - oblong, equivalent to or longer than the flowering leaf, $7-12 \mathrm{~cm}$, shorter than the fruiting leaf, 1.5-2.5 $\mathrm{cm}$. glaucous margins tinged purplish- brown, scape single with $11.5-19.5 \mathrm{~cm}$ long, greenpurplish green; raceme cylindrical; bracts entire, pinkish, triangular-oblong, pedicels equaling or slightly longer than flowers, horizontally ascending-erect 5.6-10.5mm. Flowers with 7.5-10 $\mathrm{mm}$, tubular-campanulate; perianth violaceous, length tube $3.5-6 \mathrm{~mm}$, lobes with 2-2.5 mm long, ovate- lanculate, violaceous to whitish, distinctly shorter than tube, stamens flat, narrowly triangular, basally connate filaments attached, anther purplish,1-1.5 mm reaching at least-middle of the lobes, capsule valve semilunar, cordate-broadly elliptic, triquetrous, 5$10 \mathrm{~cm}$ in dimeter, $8-17 \mathrm{~cm}$ long, thin, elliptic, retuse at apex, persistent, seed ellipsoid $2.5-3 \mathrm{X}$ 2-3 mm, black.

\section{Description of B. flexuosa}

Bulb globse wit $4-2.5 \mathrm{~cm}$ in diameter, with 4 or 5 lanculate leaves, $11-14 \mathrm{~cm}(12 \mathrm{~cm})$ in length while width 0.5-4.5 more from any species straight or truncate apex and spire base, double scape $15.5-18.5 \mathrm{~cm}$ shorter than $B$. chrisii green. Raceme cylindrical; flowers 15-25 purple to white-creamy color. The fruits are capsule $0.6-1 \mathrm{~cm}$ length and.0.5-0.8cm width elongated, with three lobes. Green Pedicels with $3.5-5 \mathrm{~cm}$ length shorter than B. chrisii. Flowering period from January to March, stamens peripetals, cylindrical filaments. Anther purplish with $3 \mathrm{~mm}$ length; seeds were spherical 3.2-3.2 $\mathrm{mm}$ in diameter, black and smooth.

\section{CONCLUSION}

Through the study, it was possible to depend on the morphological features in the taxonomy of plants, especially the shape of the elongated leaves, the presence of bulbs of different sizes, spike inflorescences crowded in some species and spread in others, the violet colour of flowers of Bellevalia species and the white of the Ornithogalum species. The shape of the fruit capsule also has a taxonomic significance that helped distinguish the species. Also the differences in seeds shapes between spherical, oval and the elongated shape of embryos are considered prominent traits of importance in the separation of species.

\section{LITERATURE CITED}

Abdul -Raheem, I. A. and Al-Bayaty, A. J. 2018. Morphoanatomical study of some species from Liliaceae Juss. Family in Ghurfa-Adhaim district. Tikrit Journal of Pure Science, 23 (6):18-23.

AL-Abide, N. M. 2013. Biosystematic study of some taxa from Chenopodiaceae in Northern and Middle Iraq. Ph. D. Thesis, Biology Department, College of Education for Pure Sciences, University of Tikrit, Iraq, 259 pp.

AL-Abide, N. M. 2016. Taxonomic morphological and anatomical study of fruits and seeds for different species of family Brassicaceae in Iraq. Kirkuk University JournalScientific Studies, 11(2): 278-296. 
AL-Abide, N. M. 2019. A morphological comparative study of some species of the Brassicaceae in the governorate of Erbil-Iraq. Plant Archives, 19 (2):289-293.

APG III (Angiosperm Phylogeny Group). 2009. An update of the angiosperm phylogeny group classification for the orders and families of flowering plants: APG III. Botanical Journal of the Linnaean Society, 161(N): 105-121.

Astuti, G., Brullo, S., Domina, G., El Mokni, R., Giordani, T. and Peruzzi, L. 2017. Phylogenetic relationships among tetraploid species of Bellevalia (Asparagaceae) endemic to south central Mediterranean. Journal Plant Biosystems - An International Journal Dealing with all Aspects of Plant Biology, 151 (6): 1120-1128.

Aykurt, C., Deniz, İ. G., Sarı, D., Vural, M. and Sümbül, H. 2016. Resurrection of Ornithogalum brevipedicellatum (Asparagaceae) with morphological and molecular data. Acta Botanica Croatica, 75(1): 60-66.

Baser, B., Firat, M. and Binzet, R. 2019. Ultrastructure and pollen in Turkey micromorphology of three endemic Bellevalia (Asparagaceae) species. Fresenius Environmental Bulletin, 28 (2A): 1065-1069.

Çitak, B. Y., Dural, H., Büyükkartal, H. N. and Pinar, N. M. 2015. Morphological, anatomical, palynological, and micromorphological characters of 2 endemic species of Ornithogalum (O. chetikianum and O. demirizianum) in Turkey. Turkish Journal of Botany, 39:48-59.

Chase, M. W., Reveal, J. L. and Fay, M. F. 2009. A subfamilial classification for the expanded asparagalean families Amaryllidaceae, Asparagaceae and Xanthorrhoeaceae. Botanical Journal of the Linnaean Society, 161(2): 132-136.

Cullen, J. 1984. Ornithogalum L. In: Davis, P. H. (ed.); Flora of Turkey and the East Aegean Islands, vol. 8, 227-244. Edinburgh University Press, Edinburgh.

Davis, P. H., Mill, R. R. and Tan K. 1988. Ornithogalum L. In: Davis, P. H. and Mill, R. R. (eds.), Flora of Turkey and the East Aegean Islands (Supplementum), vol. 10, p 223 225. Edinburgh University Press, Edinburgh.

Firat, M. 2014. Three New Species of Bellevalia Lapeyr. (Asparagaceae) from East Anatolia/ Li Kurdistana Bakur Sê Cureyên Nû Yên Bellevalia Lapeyr. (Asparagaceae) / Dogu Anadolu'da Üç Yeni Bellevalia Lapeyr. (Asparagaceae) Türü. SîTAV Yayınevi, $1^{\text {st }}$ Edition, 200 pp.

Hutchinson, J. 1959. The families of flowering plants. Second edition. Vol. 1: Dicotyledons. pp. xi + 510; Vol. 2, Monocotyledons, viii + 511-792 pp. Oxford: Clarendon Press; London: Oxford University Press. 
Comparative study of several morphological and reproductional

Jafari, A., Forghanifard, M., Farsi, M. and Behroozian, M. 2016. Comparative morphological and anatomical study on Bellevalia lapeyr. Sect. Conica and Nutans in Iran. International Journal of Biology, Pharmacy and Allied Sciences, 5(1):206-211.

Jussieu, A. L. 1789. Genera plantarum, secondum ordines naturales disposita, juxta methodum in Horto Regio Parisiensi exaratam. anno M. DCC. LXXIV (in Latin). Paris, $\mathrm{p}$ 48-49. Available at: https://www.biodiversitylibrary.org/item/7125\#page/1/mode/1up

Lapeyrouse, P. M. P. 1808. Bellevalia. Nouveau genre de plante de la famille des Liliacêes. Journal de Physique, de Chimie et d'Histoire Naturelle, 67 (12): 425-427.

Li, P. 2017. Comparative genomics and phylogenomics of East Asian tulips (Amana, Liliaceae). Frontiers in Plant Science, 8(451): 1-12.

Martinez-Azorin, M., Crespo. M. B. and Juan, A. 2010. Taxonomic revision of Ornithogalum subg. Ornithogalum (Hyacinthaceae) in the Iberian Peninsula and the Balearic Islands. Plant Systematics and Evolution, 289:181-211.

Mourad, M. M., Hamed, K. A. and Rabie, S. S. 2010. Implication of the numerical analysis of seed numerical analysis of seed characters on the taxonomic treatment of some taxa of Liliaceae. The Egyptian Society of Experimental Biology, 6(2):147-159.

Oran, A. S. and Odah, M. 2015. Ultrastructure of pollen grains of genus Ornithogalum L. (Hyacinthaceae) in Jordan. International Journal of Current Biosciences and Plant Biology, 2(9):1-6.

Peruzzi, L. 2016. A new infrafamilial taxonomic setting for Liliaceae, with a key to genera and tribes. Journal Plant Biosystems - An International Journal Dealing with all Aspects of Plant Biology, 150 (451):1341-1347.

Pinar, S. M. and Eroglu, H. 2018. Bellevalia turcica sp. nov. (Asparagaceae): a new species from South Anatolia, Turkey. Biologia, 74: 447-454.

Purger, D., Kovačić, S. and Csiky, J. 2017. Bouchê's star of Bethlehem, Ornithogalum boucheanum (Kunth). Asch. (Hyacinthaceae). a new species in flora of Croatia. Acta Botanica Croatica, 76 (2):191-195.

Shuka, L. 2014. Bellevalia hyacinthoides (Bertol.) K. Persson. New species for the Albanian Flora. Natura Montenegrina, Podgorica, 9 (3):417-420.

Townsend, C. C. and Guest, E. 1985. Flora of Iraq. Vol. 8. Baghdad: Ministry of Agriculture of the Republic of Iraq. Printed by Robert Maclehose and Company Limited printers to the University of Glasgow, $128 \mathrm{pp}$. 


\section{Sa'eed et al.}

Yetişen, K. and Özdemir, C. 2015. A morphological, anatomical and caryological study on endemic Ornithogalum alpigenum staph (Hyacinthaceae). Pakistan Journal of Botany, 47(6): 2289-2294.

Yildirim, H. and Sefali, A. 2020. Bellevalia bayburtensis (Asparagaceae): a new species from northeastern Anatolia, Turkey. Phytotaxa, 441 (3):285-293.

Yildirim, H., Altioğlu. Y., Şahin, B. and Aslan, S. 2014. Bellevalia chrisii sp. nov. (Asparagaceae) from eastern Anatolia, Turkey. Nordic Journal of Botany, 33(1):4549 . 
مقارنة بعض الجواتب المظهرية و التكاثرية لبعض الأنواع التابعة لجنسي Ornithogalum Linnaeus, و Bellevalia Lapeyrouse, 1808 1753

\section{(Asparagales, Asparagaceae)}

$$
\text { في وسط وشمال العراق }
$$

نجاة أمين سعيد*، نجلاء مصطفى العبيدي* و و عقيل حسين على العاصي

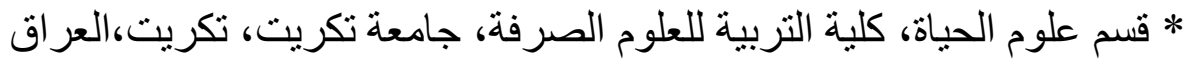

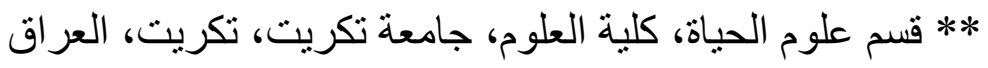

تأريخ الاستلام: 2020/08/11، تأريخ القبول: 2020/10/13، تأريخ النشر: 2020/12/21

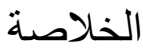

يهدف البحث الحالي إلى دراسة الخصائص المظهرية والتكاثرية لأحد

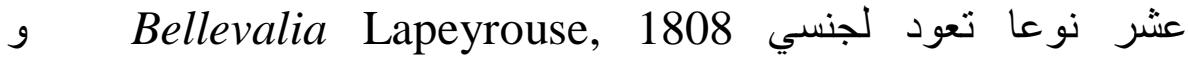
عائلة Ornithogalum Linnaeus, 1753 Asparagaceae

B. flexuosa Bellevalia chrisii Yildirim and Sahin, 2014

B. longipes $₫$ B. kurdistanica Feinbrun, 1940 !Boiss, 1854

$B$. parva $\lfloor$. macrobotrys Boissier, 1853 !Post, 1895

B. saviczii $\lfloor$ B. paradoxa Boissier, 1882 ؛Wendelbo, 1973 Ornithogalum brachystachys C. Koch, ؛Woronow, 1927 O. pyrenaicum L., g O. neurostegium Boissier, 1882؛1849

شخصت الأنواع و قورنت مع بعضها البعض ؛اذ بينت النتائج وجود

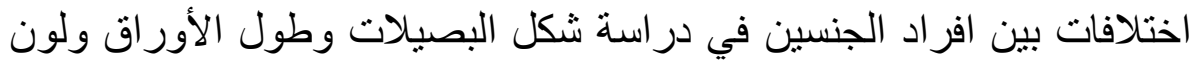

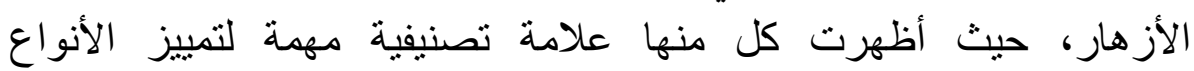
المدروسة. استخدمت الدراسات المظهرية مع بعض صفات التكاثر منها شكل

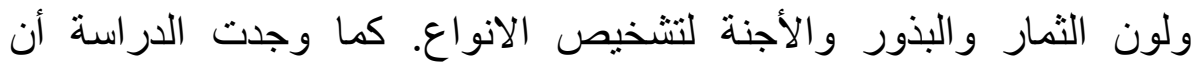


لخصائص الثمار وكيفية ارتباطها بالسويق اهمية كبيرة في مجال التصنيف و تشخيص الأنواع.

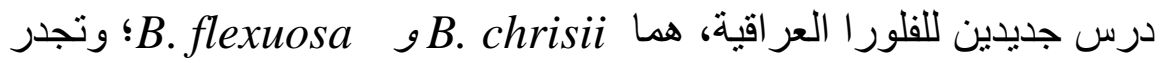
الإشارة هنا إلى أن دراسة الأجنة هي أيضا واحدة من أولى الدراسات التي التي أجريت على هذه النباتات. 